\title{
A ponte mágica: como Luísa, aos 11 anos, cria sua primeira empresa para realizar o seu sonho. São Paulo: Editora de Cultura, 2004, de Fernando Dolabela
}

\section{Sérgio Lourenço Simões}

Mestrando em Educação e professor na graduação - UnINOVE; Mestre em Lingüística - UnG.

professorsimoes@uninove.br, Mairiporã [Brasil]

No atual cenário globalizado, as distâncias se estreitam e tornam os fatos onipresentes, numa sobreposição de ações que envolvem indivíduos em luta pela sobrevivência e na busca de meios para diminuir desigualdades sociais. Nesse percurso, o homem questiona-se sobre as razões que distanciaram o ser humano de seu verdadeiro propósito: congregar esforços para atender às necessidades do "outro", ajudando-o a resgatar a identidade, a auto-estima e os valores de solidariedade por meio de ações que se firmam em pequenas causas sonhadas. Nesse contexto está a menina Luísa que, desde cedo, demonstra disposição de perseguir um sonho e de buscar meios para concretizá-lo.

O autor da obra, Fernando Dolabela, cria metodologias de ensino inovadoras no campo do empreendedorismo, que ele mesmo ajudou a formar no Brasil. De professor na área de Administração na Universidade Federal de Minas Gerais, nos anos 1990, em pouco mais de uma década concebeu e coordena os mais amplos programas de ensino do empreendedorismo no país, da educação básica à universidade. Entre seus livros publicados, O segredo de Luísa (Cultura Editores Associados), lançado em 1999, tornouse um best seller. Agora ele investe numa "novela educativa" destinada ao público infanto-juvenil no intuito de despertar o espírito empreendedor entre os mais jovens.

Neste trabalho, em que as peripécias infantis se mesclam com boa dose de ensinamentos de cunho pedagógico-educacional, Dolabela nos brinda com a história de Luísa, aos 11 anos, menina simples de Ponte Nova, interior de Minas Gerais, que vive um drama por causa de Maria, sua amiga pobre, moradora da periferia da cidade que, além de perder a casa numa enchente, havia ela própria desaparecido, levada pelas águas do rio Piranga. O fato deixa Luísa transtornada, mas não the tira o ideal projetado: comprar uma casa para a amiga; ao contrário, dá-lhe mais energia para concretizar o sonho, pois agora tem a necessidade de congregar esforços para ajudar os familiares de Maria - ainda mais necessitados - e, por extensão, o conjunto da população carente de Ponte Nova.

Para compreender melhor a proposta de Dolabela, é preciso perceber como o autor utiliza recursos metafóricos em sua narrativa para acentuar questões como firmeza de propósito, espírito empreendedor, planejamento para realizar sonhos etc. Exemplo disso é a menção da ponte do rio Piranga, chamada de ponte da Barrinha (a ponte mágica do título), que ligava os dois pólos sociais - o dos abastados e o dos menos favorecidos da cidade. Sempre que Luísa transpunha a ponte para ver a amiga, deparava com uma "realidade mágica", transformada, por momentos, na consecução de seus propósitos: "[...] as miseráveis casas de palafitas na margem [...]" (p. 18) tornam-se "[...] mansões com iates presos aos ancoradouros [...]" (p. 18), numa demonstração de que não se deve desistir da caminhada. No entanto, ao olhar para trás, vê "[...] que tudo estava como antes [...]" (p. 18). Mas, já do outro lado do rio, vinha-lhe a certeza de que deveria continuar firme em seus projetos. Para torná-los viáveis e concretizá-los, Luísa vai além; percebe que é preciso ampliar as ações solidárias, buscando parcerias, envolvendo pessoas. Para isso, promove diversas ações na escola, em seu bairro, na cidade toda.

Nessa caminhada empreendedora, com foco no projeto maior - tornar o outro melhor, dando-lhe condições de viver dignamente -, Luísa passa a utilizar o que construiu na "aula do sonho", 
como seus colegas chamavam a aula de empreendedorismo na escola, observando, questionando, seguindo as orientações de sua professora, animada com a experiência pedagógica de promover ações empreendedoras entre os alunos. Aqui o autor transporta para o universo juvenil a arte de empreender, uma vez que, para ele, essa característica acompanha o indivíduo desde o nascimento, mostrando-nos que para empreender é preciso sonhar; ao mesmo tempo dirige crítica aguda às pedagogias tradicionais que não permitem ao aluno construir seu próprio percurso, tornando-o mero depositário de conteúdos prontos.

Para Dolabela, o empreendedor (ou promotor do sonho) não é apenas aquele que cria uma empresa, mas aquele que, estando em qualquer área, pode a ela agregar novos valores, valores positivos para a coletividade, por meio de inovações. $\bigcirc$ projeto voltado para a realização de um sonho, ou seja, empreender buscando melhorar as condições de vida do outro, de uma coletividade, contrapõe-se também ao desenvolvimento de um plano com o objetivo estreito de enriquecimento pessoal. Há um enunciado ético embutido nesse conceito amplo de empreendedorismo que é oferecer valor para o coletivo e não somente para si mesmo, constituindo, assim, uma potencialidade da espécie humana. ${ }^{1}$

$\bigcirc$ autor destaca a capacidade de observação da personagem, sempre "antenada" com o que está ocorrendo a sua volta, mergulhada na realidade cotidiana, que lhe dava prazer. Luísa aprendera a questionar, a analisar os padrões sociais, a discernir entre o certo e o errado. Em sua inocência, não se prendia a convenções, ainda não estava impregnada de preconceitos nem precisava fazer concessões em seu percurso, e sim acreditar apenas na concretização de um sonho. Lembrava-se do que the dissera a amiga Maria "- Olha, o sonho é muito bom, porque é algo que nasce dentro da gente, nós somos donas dele. Mas melhor do que sonhar é correr atrás do sonho [...]" (p. 21).

Por meio desse espírito infantil e povoado de indagações, que acredita ser a utopia o plenamente realizável, até inconscientemente, pela pureza de olhar e de coração, libertos dos vícios engendrados por relações e interesses escusos, em que se fazem presentes os artifícios para conquista de poder e status e para satisfação de vaidades pessoais, Dolabela nos sugere a possibilidade de reavaliar, de maneira sutil, os "escombros" de uma sociedade capitalista perversa que, em nome de ações assistencialistas, promove a discriminação e exclusão do indivíduo, corroborando, em certa medida, as mazelas sociais.

Com este livro, Dolabela complementa seu ambicioso projeto pedagógico iniciado em Oficina do empreendedor (Cultura Editores Associados, 1999) - dirigido especialmente aos cursos de graduação e alguns de pós-graduação das faculdades de Administração e afins -, seguido pelo já comentado $O$ segredo de Luísa, destinado a um público mais amplo, e fechado com este $A$ ponte mágica, destinado a um público de 11 a 17 anos. A obra, de agradável leitura, convida à reflexão sobre valores éticos, à reavaliação de atitudes, despertando o interesse e a necessidade de estabelecer relações, além de proporcionar novas leituras de mundo. Mais do que um romance para o público infanto-juvenil, esta obra vem contribuir para que professores e demais profissionais possam dar novos significados a sua prática e promover o bem-estar social.

\section{Notas}

1 N. do Ed.: Sobre o tema, veja entrevista de Fernando Dolabela nesta edição. 